\title{
ОПЫТ ИСПОЛЬЗОВАНИЯ ФИЗИЧЕСКОЙ НАГРУЗКИ КАК ВАРИАНТ ОБУЧЕНИЯ ДЕТЕЙ С САХАРНЫМ ДИАБЕТОМ 1 ТИПА И ИХ РОДИТЕЛЕЙ
}

\author{
Власенко Н.Ю., Юдицкая Т.А., Захаров И.Л., Пилипенко Л.С., Юнгман Н.В., Каргаполова К.И., Кузнецова П.В., \\ Смородина А.С., Ковтунова Е.С.
}

АКТУАЛЬНОСТЬ: неотъемлемой частью работы с пациентами является их обучение в «Школе сахарного диабета». Однако ряд навыков необходимо закреплять на практике, в том числе и раздел «Физическая нагрузка».

ЦЕЛЬ: оценить уровень знаний пациентов и их родителей о физической нагрузке, питании перед и после тренировок, способах оказания помощи при гипогликемии. Показать изменения гликемии при физической нагрузке у каждого конкретного пациента.

ПАЦИЕНТЫ И МЕТОДЫ: пациенты с сахарным диабетом в возрасте 7-12 лет, принявшие участие в 8 танцевальных тренировках, продолжительностью 1 час (4 недели). Участникам проводили измерение гликемии до и после тренировки, оценку гликозилированного гемоглобина в начале, анкетирование.

РЕзУЛЬтАты: при поддержке Региональной Общественной организации «Омское диабетическое общество инвалидов» (РОО «ДиаОмск») для пациентов регулярно проводятся образовательные, оздоровительные и развлекательные мероприятия. Обязательной частью встречи является физическая активность детей - плавание в бассейне с родителями (в сопровождении врача), спортивные игры на воздухе.

Осенью 2019 года РОО «ДиаОмск» совместно с врачами детскими эндокринологами на протяжении 1 месяца было запланировано проведение Велнесс-тренинг для детской (7-12 лет) и взрослой (с 13 лет) групп. Первые сложности возникли во время набора пациентов для участия в тренинге - родители очень неохотно соглашались менять привычный уклад жизни, подростки ссылались на «недостаток времени», в старшей группе занималось только 2 девочки.

В группе 7-12 лет занималось 8 детей со стажем заболевания от 2 мес до 6 лет. Контроль гликемии осуществлялся глюкометрами, в 5 случаях дети использовали индивидуальные приборы для непрерывного мониторирования гликемии. Четверо обследуемых получали помповую инсулинотерапию препаратом NovoRapid. Остальные пациенты получали МИИ препаратом NovoRapid/Degludec или Detemir. В обследуемой группе только 2 ребенка раньше занимались физической активностью - танцы, плавание и единоборства.

Уровень гликозилированного гемоглобина в начале тренировок был 6,9-8,5\%. За время проведения тренировок цифры гликемии были нестабильны, трудно отметить единый тренд в изменении кривой. У одних пациентов отмечалось снижение показателя уже через 30 минут от начала тренировки. Другие к концу часа занятий имели более высокие показатели, чем в начале тренировки. Только 2 пациента после второй тренировки отметили гипогликемию. Обращало на себя внимание, что родители «не знали», что перед тренировкой необходим прием пищи. Большинство не имело с собой на тренировке ни глюкометра (только 2 пациента с первого занятия измеряли гликемию каждые 30 минут), ни средств для оказания помощи при легкой гипогликемии. С каждой последующей тренировкой динамика гликемии была более объяснимой и подготовка пациентов соответствующей.

ВЫвОды: при проведении велнесс-тренинга была выявлена недостаточная активность родителей, недостаточные знания у детей и родителей по подготовке к физической нагрузке. При этом все дети, принявшие участие в тренинге были очень исполнительными и внимательно выполняли все требования тренера и врача. Средства непрерывного мониторирования гликемии являются неоспоримым преимуществом при повышенной физической активности.

КЛЮЧЕВЫЕ СЛОВА: сахарный диабет 1 mипа; дети; физическая нагрузка; обучение. 